\title{
Developing Media Rich Virtual Learning Material for Biomedical Engineering Education
}

\author{
A. Kybartaite, J. Nousiainen and J. Malmivuo \\ Tampere University of Technology
}

\begin{abstract}
Not all universities, and especially newly established institutes in biomedical engineering are able to develop and provide a high quality learning content. A distant, open and free learning environment - European Virtual Campus for Biomedical Engineering (EVICAB) - could provide a solution for that. The learning content has been already developed for EVICAB and is available in different formats, i.e., text based material delivered as HTML or PDF documents, animated material, electronic textbook, audio and video based material. Video based material is a multimedia application with considerable promise for teaching and learning in the higher education. Video lectures as a learning tool have been produced and tested in EVICAB. The preliminary findings show the results that encourage further developments of the e-learning material, including video lectures, for the Virtual Campus for Biomedical Engineering.
\end{abstract}

Keywords- Biomedical Engineering, e-Education, Video Lectures.

\section{INTRODUCTION}

Biomedical engineering is a multidisciplinary field of study combining engineering with life sciences and medicine [1]. A critical goal of biomedical engineering education is the introduction of the students to some of the techniques necessary to apply engineering problem solving to living organisms and systems [2]. Educational programs in the field of biomedical engineering had their origins in the 1950s as several formalized training programs were created [1]. By 2005, more than 200 universities of applied science, polytechnic schools, academies and other institutions in Europe offered educational programs in biomedical engineering at all academic levels [3]. Further, the survey conducted in 2006 revealed that about 9\% of educational centers around the Europe (belonging to EU) already provide or plan to provide distance courses for biomedical engineering education [4]. Distance teaching and learning (i.e., electronic, virtual, Internet-based, web-based, or computermediated) is seen as a future trend in the higher education [5].

As biomedical engineering is a relatively new and diverse field of study that has only recently experienced sufficient maturity to set its own identity, not all universities, and especially newly established institutes in biomedical engineering are able to develop and provide a high quality up-to-date teaching and learning materials. Distant, open and free virtual learning environment could offer possibility to access high quality learning content for all students, i.e., seeking university degree, virtual, exchange, visiting, international program students; and make the teaching and learning more flexible, not limited by time, place or pace. European Virtual Campus for Biomedical Engineering (EVICAB) is the solution for that.

EVICAB started in January, 2006 as the European Commission funded project. The aim of the project was to develop, build up and evaluate sustainable, dynamic solution for virtual mobility and e-learning in the field of biomedical engineering and medical physics [6].

Several different modalities have been used to develop content for EVICAB: (1) text based material delivered as HTML or PDF documents; (2) hypertext material connected text, multimedia and exercises in a meaningful way; (3) animated material enriched text-oriented material by animations and made the content and appearance more interesting; (4) electronic textbook material followed specific textbook; (5) audio based material enhanced text transcription of the lectures; (6) video based material connected face-to-face classroom course with recorded lecturer speaking and presentation or online examples used for illustration.

Video based material is a multimedia application with considerable promise for teaching and learning in the higher education [7]. The main areas where the video based material is especially effective are: (1) to grasp students' attention and motivate them to learn; (2) to provide highly realistic depiction of situation which students would not otherwise have the occasion to see e.g., medical procedure; (3) to watch again/ later recorded (videoed) live face-to-face lectures.

Our gathered information and experience when developing video lectures related to biomedical engineering is presented in this paper. 


\section{Materials AND METHODS}

\section{A. Theoretical approach: Modeling video lectures}

"The aim of teaching is simple: it is to make student learning possible". While the aim is simple, the process is complex because it involves an array of understandings from discipline perspectives to which students are being introduced and in which they are invited to operate [8].

In order to understand how to make the virtual education for biomedical engineering more acceptable by teachers and students we reviewed related learning theories (see Table 1).

Table 1 Connecting learning theories to virtual education

\begin{tabular}{|c|c|c|}
\hline Theory/ Model & Key issue & Reference \\
\hline $\begin{array}{l}\text { Paivio’s Dual } \\
\text { Coding Theory } \\
\text { (1986) }\end{array}$ & $\begin{array}{l}\text { Postulates that both visual and verbal } \\
\text { codes for representing information are used } \\
\text { to organize incoming information into } \\
\text { knowledge that can be acted upon, stored, } \\
\text { and retrieved for subsequent use. }\end{array}$ & [9], [10] \\
\hline $\begin{array}{l}\text { Severin’s Cue } \\
\text { Summation } \\
\text { theory (1967) }\end{array}$ & $\begin{array}{l}\text { States that learning is increased as the } \\
\text { number of available stimuli is increased. } \\
\text { The stimuli provided on different channels } \\
\text { have to be relevant to each other or the } \\
\text { distraction would cause a decrease rather } \\
\text { than an increase in learning and retention. } \\
\text { Deals specifically with learning and reten- } \\
\text { tion in a multimedia environment. }\end{array}$ & [9], [10] \\
\hline $\begin{array}{l}\text { Atkinson- } \\
\text { Shiffrin Model } \\
(1968)\end{array}$ & $\begin{array}{l}\text { Proposes multi-store or multi-memory } \\
\text { model for the structure of memory. It states } \\
\text { human memory is a sequence of three } \\
\text { stages: (1) sensory memory, (2) short-term } \\
\text { memory, (3) long-term memory. }\end{array}$ & {$[10]$} \\
\hline $\begin{array}{l}\text { Baddeley’s } \\
\text { Theory of } \\
\text { Working }\end{array}$ & $\begin{array}{l}\text { The model is composed of three main } \\
\text { components; the central executive which } \\
\text { acts as supervisory system and controls the } \\
\text { flow of information from and to its slave } \\
\text { systems: the phonological loop, visuo- } \\
\text { spatial sketchpad, and episodic buffer. The } \\
\text { slave systems are short-term storage } \\
\text { systems dedicated to a content domain } \\
\text { (i.e., verbal and visuo-spatial). }\end{array}$ & [10] \\
\hline $\begin{array}{l}\text { Sweller's } \\
\text { Cognitive } \\
\text { Load Theory } \\
\text { (1988) }\end{array}$ & $\begin{array}{l}\text { Refers to the load on working memory } \\
\text { during problem solving, thinking and } \\
\text { reasoning (including perception, memory, } \\
\text { language, etc) }\end{array}$ & [9], [10] \\
\hline $\begin{array}{l}\text { Wittrock's } \\
\text { Generative } \\
\text { Learning } \\
\text { Theory (1989) }\end{array}$ & $\begin{array}{l}\text { Promotes less reliance on professor's } \\
\text { lectures while simultaneously creating } \\
\text { more self-reliance among students. }\end{array}$ & [10] \\
\hline $\begin{array}{l}\text { Mayer's } \\
\text { Selecting- } \\
\text { Organizing- } \\
\text { Integrating } \\
\text { (SOI) theory } \\
\text { of active } \\
\text { learning }\end{array}$ & $\begin{array}{l}\text { States that the promise of multimedia } \\
\text { learning is that teachers can tap the power } \\
\text { of visual and verbal forms of expression in } \\
\text { the service of promoting student } \\
\text { understanding. }\end{array}$ & [10] \\
\hline
\end{tabular}

\begin{tabular}{lll}
\hline Constructivism & $\begin{array}{l}\text { States that: (1) knowledge is constructed, } \\
\text { not transmitted, (2) prior knowledge } \\
\text { impacts the learning process, (3) initial } \\
\text { understanding is local, not global, (4) } \\
\text { building useful knowledge structures } \\
\text { requires effortful and purposeful activity. }\end{array}$ \\
\hline $\begin{array}{l}\text { Gagne's } \\
\text { Information }\end{array}$ & $\begin{array}{l}\text { Stipulates that there are several different } \\
\text { Processing }\end{array}$ & [9], [10] \\
theory & $\begin{array}{l}\text { cance of these classifications is that each } \\
\text { different type requires different types of } \\
\text { instruction. Gagne identifies five major }\end{array}$ \\
& $\begin{array}{l}\text { categories of learning: verbal information, } \\
\text { intellectual skills, cognitive strategies, } \\
\text { motor skills and attitudes. Different inter- } \\
\text { nal and external conditions are necessary } \\
\text { for each type of learning. }\end{array}$ \\
\hline
\end{tabular}

The reviewed learning theories support virtual education, e.g., by promoting more self reliance among students, following principle of knowledge construction, supporting different types and levels of learning, including multimedia and video based material in education.

The application of virtual education and video based material in education is not a new endeavor. A projects of combination of recorded lectures and accompanying presentations available via the WWW web have been developed by many institutions, e.g., Tutored Video Instructions, Distributed TVI [12], eClass [13], Georgia Tech HumanCentered Computing Education Digital Library [14], eTeach [15], Webcast Berkeley [16], MIT Open Course Ware [17], Videolectures.NET [18], [26], Free video lectures [19].

Many more examples are available. Based on these examples we defined advantages and disadvantages of the video lectures (Table 2 and 3).

Table 2 Advantages of the video lectures

Allows grabbing student's attention and presenting information that is easy to absorb.

Provides high effect for student's motivation, training and instructions.

Helps to comprehend hard-to-understand concepts and engage in the learning process.

On-campus and off-campus learners can participate in the same learning program.

Provides flexibility for choosing learning place, pace and time.

Provides flexibility to use different equipments, gadgets for learning.

Provides possibility to adopt more flexible learning patterns.

Provides possibility to see recorded lectures given by eminent professor who would not be able to travel to a higher institution more than once.

Offers possibility to become self-sufficient learners.

Students may watch video lectures before attending workshop so that material contained in it might be explored in depth.

Students can better prepare for assessment.

Students can watch video over again until the skill has been mastered.

Students can stop, start and rewind the video to address their specific needs. 
Students can watch video lectures to enrich their learning notes. Allows students to catch up if they miss a face-to-face lecture. Learning material can be accessed and transferred very fast.

Table 3 Disadvantages of the video lectures

Technical problems, e.g., computer access or Internet connection might be limited.

Quality issues.

Viewer is less forgiving of the lecturer's minor mistake and audience disruption when watching video lectures.

Re watching video lectures can become dull and repetitive learning process.

Students might see video lectures as the only source of knowledge, this could remove students' need to consult other sources, and hence reduce the opportunity to develop as individual learners.

Fast accessing of learning material might diminish the importance of constructing knowledge.

No direct interaction with lecturer, no possibility to ask direct questions.

Video lectures can have adverse effect for attendance.

Technology, e.g., software for producing video lectures is not yet mature.

In order to utilize the advantages and to find solutions for the disadvantages we implemented a practical model to develop the video lectures.

\section{A. Practical approach: Model to develop video lectures}

A video lecture is a combination of a moving image, accompanying sound and synchronized presentation. We see three levels at which video lecture may operate: (1) transmit information, (2) encourage reflection, (3) promote dialog. There are different approaches how to produce video lectures, e.g., (1) videoing lecturer, capturing his speech and displaying all information in one frame, (2) videoing lecturer and displaying presentation along site in a separate frame, (3) recording lecturer's voice and synchronizing with a presentation or graphical information, etc.

The process of developing video lectures can be divided into several steps: (1) research on the related technologies including software and hardware, (2) research on the lecture, its content, duration, presentation type, (3) test of the technologies in the real environment, (4) recording video lectures, (5) production of the video lectures including edition and synchronization of video, audio files and presentation, segmenting into easy to absorb parts, arranging table of content, (6) publishing via the Internet, web editing and web serving, (7) providing supporting information, e.g., computer or software requirements in order to access the video lectures.

The process of developing video lectures may vary on experience and available technologies. The quality of video lectures depends on each step. Despite advanced planning unexpected issues can occur during the recording; the most common that a microphone can produce extra noise; recording time can be extended due to the class discussion, etc. So some possible assistance should be arranged in advanced.

The step of production of video lectures for EVICAB was an experimental process. We started by using Synchronized Multimedia Integration Language (SMIL). SMIL code was provided by Hypermedia Laboratory in Tampere University of Technology. The benefit of the code was the possibility to change the lay-out, table of content and size of frames in the video lecture. These features are quite limited in commercial software [20]. Despite that we found the disadvantage: video lectures were viewable only with Real Player. As Flash Player is more and more used to deliver rich media content with video, graphs and animations we decided to use commercial software [21] and produce video lectures in the Flash format. After experimenting and testing all video lectures were produced in the same way.

\section{Results}

\section{A. Metadata of EVICAB lectures}

Five video lectures have been produced for EVICAB. They are divided into three groups: bioelectromagnetism, optics, and signal analysis (Fig. 1). The levels of the lectures are different, i.e., introductory, middle or advanced level. Despite that, all the lectures have additional supporting materials, i.e., textbook, e-book, presentation or lab works. The supporting materials vary within the lectures. Bioelectromagnetism lectures can be presented as an example; they are supported by textbook, e-book, and quizzes for self-evaluation. So students can refer to the type of the learning material which is the most convenient for them and make their studies independent of the time or place. 


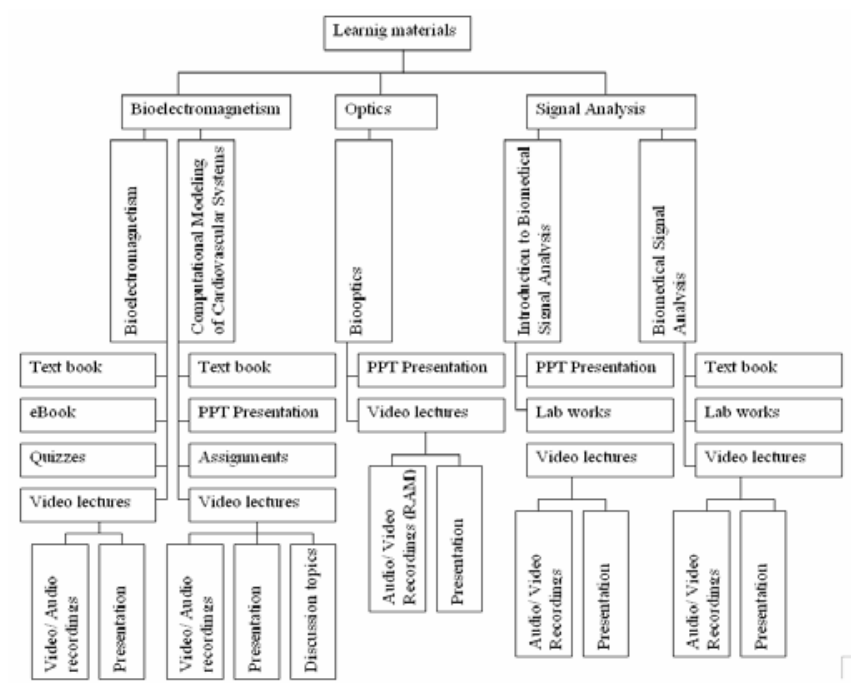

Fig. 1 Metadata for EVICAB lectures

In addition, the elements that make video lectures, i.e., audio/ video recordings and presentations could be used as reusable learning objects (RO) by other instructors. A common bank for ROs could be created and be assessable only by permission of the authors.

\section{B. Evaluation of the video lectures}

The preliminary evaluation of the video lectures was performed. It was important to obtain students' opinions for the further developments. The evaluation was based on the questionnaire form. Traditional five-point Likert scale was used to evaluate the usefulness, technical quality, and pedagogical value (Table 4). 18 students, who participated in Bioelectromagnetism course, Tampere University of Technology, 2007 autumn, provided their opinions. The course was available as traditional classroom activity or via e-learning environment.

Table 4 Average evaluation of the video lectures

\begin{tabular}{lc}
\hline Evaluated issue & Average evaluation \\
\hline Usefulness of the video lectures & 4,29 \\
\hline \multicolumn{2}{l}{ Usefulness of traditional classroom lectures } \\
\hline \multicolumn{2}{l}{ Technical quality of the video lectures } \\
\hline$\bullet \quad$ Audio quality & 4,67 \\
\hline$\bullet \quad$ Video quality & 3,86 \\
\hline$\bullet \quad$ Presentation & 4,07 \\
\hline Pedagogical value & 4 \\
\hline
\end{tabular}

The used scale was from 1 to 5 , where 1 meant satisfactory evaluation and 5 - excellent evaluation.
The evaluation also revealed that approximately half of the responded students spent most of their study time for attending traditional classroom activities and the other half preferred e-learning activities, like studying video lectures, e-book, making e-assignments. Knowing that video lectures were an experiment, the results were positive.

In addition, we inquired what students expected from the e-material? Most of all, students expected: (1) animations that would enrich text-oriented learning material, (2) clear instruction in written format, and (3) learning material in video format. These expectations approved that students would accept video lectures and encouraged for the further developments.

\section{Discussion}

Literature [9] provides comparative analysis between three different types of modality combinations in the webbased learning environment in terms of the outcomes perceived by the students, i.e., (1) text + graphics, (2) text + graphics + audio, and (3) text + graphics + video. The Post Hoc Test for multiple comparisons revealed the hierarchical modality combination; text + graphics + audio exhibited the highest mean score. The modality combination of text + graphics + video exhibited the lowest mean score. The reasons for that were analyzed based on various theories and possible explanations include that students were not familiar with the combination of the video + sound, which might distracted their concentration. Video streaming created a new video page which overlapped with screen text, hence loosing concentration on the course content. Another possible explanation was the degradation of the information processing when more modalities were added because of the increase of cognitive load which leads to less effective processing of information in the brain.

In our case, we could compare different learning environments in terms of the outcomes perceived by the students, i.e., results of the final exam of the students who participated in the traditional class activities and who studied using video lectures with supporting materials via the elearning environment. The summated results show that independent whether the students participated in the traditional class activities or used video lectures, learning outcomes were quite the same, i.e., the average grade of the final exam was 3 (using grade scale from 1 to 5 ).

The combination of audio + video + presentation was well accepted by students in terms of usefulness, technical quality and pedagogical value (average evaluation 4). The main reason, we see, why a low number of students used video lectures is the fact that students were not familiar with 
the video lectures and their applications. Still, more than half of the responded students (61\%) preferred traditional classroom activity as the only learning method. Technical limitations could also discourage students to watch the video lectures, e.g., slow Internet connection or personal computer properties.

We noticed that more students become interested in elearning activities, including video lectures. Thus future improvements are needed. They should focus on capturing, integration and access processes [13]. In the video capture process, a system should be able to support generalized capture of the lecture materials without any extra instructor effort. The integration of video, audio and graphical presentation should be smarter; e.g., more semantic linking of the data. The access of video materials should support generalized replay, i.e., start, stop or rewind the video to address a specific need, rather than just showing the static result. Also the access interface could increase the value of video lectures, e.g., adding possibility for collaboration, interactive communication, discussion, linking to the other related sources of information, etc. The access interface should support more than just lecture review so the future work could be devoted for improving it.

\section{ConClusion}

The idea behind video lectures is not to substitute a class activity or to eliminate the lecturer but to support and augment the teaching and learning process for biomedical engineering.

Modern pedagogically based e-learning material taking advantages of developments in technology and combined with appropriate learning theories supports the suggestion that students should be able to achieve higher learning outcomes.

\section{AcKnowledgment}

\section{REFERENCES}

1. P. Benkeser. Biomedical Engineering Education. Encyclopedia of Medical Devices and Instrumentation. 2006

2. P.D. Schreuders, A. Johnson. A System Approach for Bioengineering. International Journal of Engineering Education, 1999. 15(4): p.234248.
3. Biomedea. Criteria for the Accreditation of Biomedical Engineering Programs in Europe, 2005

4. E.G. Salerud, H. Petersson, M.A. Ilias. European Biomedical Engineering/ Survey Report of Existing and Planned BME Distance Courses in Europe. EVICAB report, 2006

5. P. Pasternack, r. Bloch, C. Gellert, M. Hölscher, R. Kreckel, D. L Ewin, I. Lischka, A. Schidberg. Current and Future Trends in Higher Education/ Summary.

6. EVICAB. Available at www.evicab.eu

7. J.Whatley, A. Ahmad. Using Video to Record Summary Lectures to Aid Student's Revision. Interdisciplinary Journal of Knowledge and Learning Objects, 2007, 3

8. S. Magennis, A. Farrell. Teaching and Learning Activities: Expanding the Repertoire to Support Student Learning. In Emerging Issues in the Practice of University Learning and Teaching, 2005. Available at: www.aishe.org/readings/2005-1/

9. P. Kaur, H. Atan, S.F. Fong, R.M. Idrus, H. Dzakiria. The Combination of Different Modalities in the Web-Based Learning Environment: A Comparative Analysis of the Perceptual instructional Outcomes. 2005, Proceedings of the Fifth IEEE International Conference on Advanced Learning Technologies.

10. R. Mayer. Multimedia Learning. 2001, Cambridge University Press.

11. Scientific Reasoning Research Institute. Constructivism. Available at: http://srri.umass.edu/topics/constructivism

12. M.J. Sipusic, R.L. Pannoni, R.B. Smith, J. Dutra, J.F. Gibbons, W.R. Sutherland. Virtual collaborative Learning: A Comparison between Face-to-Face Tutored Video Instruction (TVI) and Distributed Tutored Video Instruction (DTVI), 1999

13. J.A. Brotherton, G.D. Abowd. Lessons Learned from eClass: Assessing Automated Capture and Access in the Classroom. 2004, ACM Transactions on Computer-Human Interaction, 11 (2).

14. J.A. Day, J. D. Foley. Evaluating a Web Lecture Intervention in a Human-Computer Interaction Course. 2006, IEEE.

15. G. Moses, M. Litzkow, J. Foertsch, J. Strikwerda. eTeach - A Proven Learning Technology for Education Reform. 2002, 32 ${ }^{\text {nd }}$ ASEE/ IEEE Frontiers in Education Conference.

16. Webcast Berkeley. Available on: http://webcast.berkeley.edu/

17. MIT Open Course Ware. Available at: http://ocw.mit.edu/OcwWeb/web/courses/av/index.htm

18. Videolectures.NET. Available at: http://videolectures.net/

19. Free Video Lectures. Available at: http://freevideolectures.com/

20. K. Lindroos, J. Malmivuo, J. Nousiainen. Web-based Supporting Material for Biomedical Engineering Education. 2007, IFMBE Proceedings.

21. Camtasia Studio. Available at: http://www.techsmith.com/camtasia.asp

Author:

Institute:

Street:

City:

Country:

Email 